\title{
CECHY REŻIMU ODPŁYWU RZEK KOTLINY KŁODZKIEJ
}

\author{
ADAM PERZ \\ Zakład Hydrologii i Gospodarki Wodnej, Wydział Nauk Geograficznych i Geologicznych, \\ Uniwersytet im. Adama Mickiewicza w Poznaniu, ul. B. Krygowskiego 10, 61-680 Poznań \\ ORCID 0000-0002-2497-4390
}

\begin{abstract}
This paper seeks to identify the features of the flow regime of the rivers in Kłodzka Valley in terms of the runoff, the structure and the spatiotemporal variabilities. The analysis was carried out on the basis of data provided by the Institute of Meteorology and Water Management from the period of 1971-2015 and obtained from 8 gauging stations located in 5 rivers. The research embraced the Nysa Kłodzka river and its main tributaries to the gauging station in Kłodzko. The runoff conditions in the analysed sub-basins are different. As a result, the rivers in Kłodzka Valley have different regime features. Due to the regularities in their flow variability, they can be classified into 2 types of hydrological regime: nival and nival-pluvial. There are significant differences in the total runoff, from $375 \mathrm{~mm}$ in Kłodzko to above $700 \mathrm{~mm}$ in the Wilczka river. The differences also occur in terms of the groundwater runoff and its contribution to the total runoff which ranges between $31 \%$ and $53 \%$. All of the analysed basins have contributions to groundwater runoff below the mean value for the entire country $(55 \%)$. In terms of viabilities of discharges, in general there are differences between the upper Nysa Kłodzka and its eastern tributaries and the western part of the basin.
\end{abstract}

Keywords: Kłodzka Valley, river runoff, hydrological regime

\section{WSTĘP}

W dobie zmian klimatycznych i postępującej antropopresji, a także zwiększającego się ryzyka związanego $\mathrm{z}$ występowaniem zdarzeń ekstremlanych w postaci powodzi i suszy szczególnie istotne jest właściwe ustalenie cech reżimu hydrologicznego, zwłasza w kontekście stabilności warunków odpływu. Odpowiednie gospodarowanie zasobami wodnymi, przede wszystkim w zakresie zapewnienia ich odpowiednich zapasów w czasie niedoboru wody, jak i ochrony przeciwpowodziowej w okresie jej nadmiaru jest kluczowym wyzwaniem, mającym wpływ na wszystkie aspekty życia i działalności ludzi oraz środowisko przyrodnicze i ich wzajemne powiązania. W związku z tym badanie cech reżimu odpływu i jego stabilności nie ma jedynie znaczenia naukowego, ale jest równie istotne $\mathrm{z}$ aplikacyjnego punktu widzenia. Celem niniejszej pracy jest identyfikacja cech reżimu hydrologicznego Nysy Kłodzkiej i jej dopływów po wodowskaz Kłodzko w zakresie wielkości odpływu, jego struktury oraz zmienności.

Sudety, do których należy obszar badań, wraz z Przedgórzem Sudeckim są drugim regionem Polski pod względem wielkości zasobów wodnych (Bednorz 
i in. 2019). Czyni go to jednak podatnym na występowanie wezbrań, a także duże powodzie. Powstało kilka opracowań monograficznych, w których opisano powodzie, np. w lipcu 1970 r. (Morawska-Horawska 1971), w lipcu 1997 r. (Dubicki i in. 1999; Świątek 2013) oraz w maju i czerwcu 2010 r. (Szalińska $i$ in. 2014). Łach (2009) przeanalizował wezbrania na Nysie Kłodzkiej i jej dopływach od XIII w. i wskazał, że od XIII w. do końca XIX w. skutkiem powodzi była nadbudowa den dolinnych, natomiast od XX w. procesy takie występują jedynie lokalnie, obserwuje się wcinanie rzek w swoje aluwia. Bednorz $\mathrm{i}$ in. (2019) wskazują na osadzenie koryt rzecznych w starszych utworach oraz koncentryczny układ sieci rzecznej Kotliny Kłodzkiej jako warunki sprzyjające formowaniu się wysokich stanów i fal powodziowych na rzekach. W badaniach Masyw Śnieżnika, w którym znajdują się źródła Nysy Kłodzkiej, traktuje się jako jeden z obszarów najbardziej podatnych na występowanie wezbrań związanych z wysokimi opadami atmosferycznymi (Wrona 2008; Bednorz i in. 2019). Zarówno warunki klimatyczne, jak i pozostałe cechy środowiska geograficznego składają się na wezbranio- i powodziogenny charakter zlewni Ziemi Kłodzkiej, która bardzo szybko reaguje na opad (Tokarczyk, Olearczyk 2011). W związku z powyższym rzeki tego obszaru są m.in. przedmiotem licznych modeli hydrologicznych i hydraulicznych (m.in. Szalińska i in. 2014; Rutkowska i in. 2017; Niedzielski, Miziński 2017; Jeziorska, Niedzielski 2018; Stodolak i in. 2018).

Badaniem odpływu i jego struktury oraz typologią reżimów odpływu rzek zajmowało się wielu autorów. Wrzesiński $(2017 \mathrm{a}, \mathrm{b})$ przedstawił różne typologie reżimu odpływu rzek w Polsce w podejściu nadzorowanym i nienadzorowanym. Jedną z najczęściej wykorzystywanych typologii reżimu odpływu jest klasyfikacja Dynowskiej (1999), zastosowana również w niniejszej pracy.

\section{OBSZAR BADAŃ}

Obszar badań - Kotlina Kłodzka - w niniejszej pracy rozumiany jest jako teren odwadniany przez odcinek Nysy Kłodzkiej po Kłodzko. Leży on w południowej części Polski, należy do podprowincji Sudety z Przedgórzem Sudeckim, do dwóch makroregionów: Sudety Środkowe i Sudety Wschodnie. Obszar ten obejmuje następujące mezoregiony: Rów Górnej Nysy, Masyw Śnieżnika, Góry Złote, Góry Bardzkie, Góry Bystrzyckie, Góry Orlickie, Góry Stołowe, Kotlina Kłodzka i Obniżenie Ścinawki (Kondracki 2013; Solon i in. 2018) (ryc. 1).

Kotlina Kłodzka (wg wydzielenia Kondrackiego), a w nowym podziale fizycznogeograficznym Polski Rów Górnej Nysy i Kotlina Kłodzka (wg Solona $i$ in. 2018) jest rowem tektonicznym o kierunku południkowym, dzielącym Sudety na część środkową i wschodnią (Kondracki 2013). Od zachodu ograniczają ją Góry Bystrzyckie, od wschodniej strony Masyw Śnieżnika, Góry Złote i Góry Bardzkie (Kondracki 2013). Kotlina nie ma wyraźnie zarysowanej 


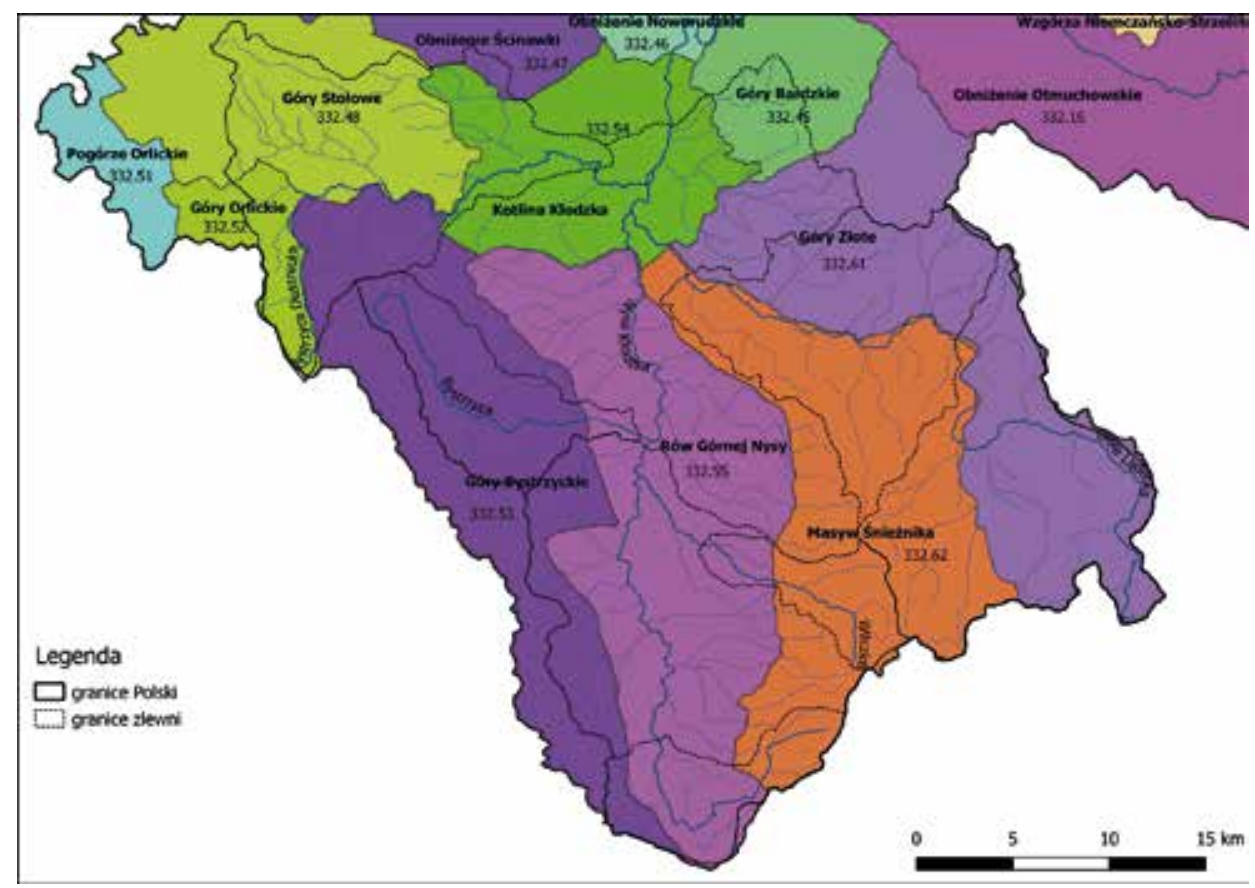

Ryc. 1. Obszar badań na tle podziału fizycznogeograficznego Polski - mezoregiony (na podstawie Solon i in. 2018)

Fig. 1. Area of research against the background of the physical-geographical division of Poland mesoregions (on the basis of Solon et al. 2018)

granicy północnej, jej przedłużeniem jest Obniżenie Ścinawki oraz Obniżenie Noworudzkie (Kondracki 2013). Obszar ten charakteryzuje się stosunkowo dużym zróżnicowaniem wysokości - np. Trójmorski Wierch sięga 1145 m n.p.m., natomiast najniższa część Kłodzka leży na wysokości około 280 m n.p.m. (ryc. 5).

Pod względem geologicznym Kotlina Kłodzka odznacza się niewielką zmiennością (Łach 2012) - na obszarze dominują prekambryjskie skały metamorficzne oraz osadowe skały wieku kredowego. Kotlina Kłodzka jest natomiast zróżnicowana pod względem strukturalnym i teksturalnym, a także odporności skał na procesy erozyjne i wietrzeniowe (Łach 2012). Obszar ten charakteryzuje rzeźba falista i pagórkowata, średniogórska, której istotnym elementem są doliny rzeczne cechujące się odrębnym wyrazem morfologicznym oraz różnym stopniem rozwinięcia systemu korytowego (Lach 2012). Poza osadami rzecznymi w dolinach zachowały się pozostałości pokryw morenowych i iłów zastoiskowych - wynik dwukrotnego nasunięcia się lodowca kontynentalnego przez przełęcze Gór Bardzkich (Kondracki 2013). Dno kotliny pokrywa częściowo less, na którym wykształciły się żyzne gleby. Sprzyjało to rozwojowi rolnictwa, a rezultatem jest znaczne wylesienie terenu (Kondracki 2013). 
Najważniejszą rzeką Kotliny Kłodzkiej jest Nysa Kłodzka, mająca źródła w Masywie Śnieżnika, na zboczu Trójmorskiego Wierchu, na wysokości ponad 1000 m n.p.m. Początkowo płynie Rowem Górnej Nysy, który stanowi naturalny kanał odpływowy (Staff 1993). Następnie wpływa we właściwą Kotlinę Kłodzką, gdzie zachowuje swój górski charakter aż do wypłynięcia z Gór Bardzkich, za którymi zaczyna meandrować i nabiera cech rzeki nizinnej. Ostatecznie uchodzi do Odry. Jej łączna długość wynosi około 181,7 km. Jej główne dopływy w obrębie analizowanego obszaru to: Wilczka (18,2 km), Bystrzyca $(25,5 \mathrm{~km})$, Biała Lądecka $(52,7 \mathrm{~km})$ oraz Bystrzyca Dusznicka $(33 \mathrm{~km})$. Górski charakter tych cieków, rzeźba terenu oraz geologia powodują, że w wyniku gwałtownych lub długotrwałych opadów oraz odwilży bardzo łatwo formują się na nich fale wezbraniowe. Może o tym świadczyć np. letnia powódź z lipca 1997 r., zwana „powodzią tysiąclecia”. Spowodowała ona ogromne straty materialne nie tylko na Ziemi Kłodzkiej, ale również w nadodrzańskich miastach, w tym we Wrocławiu, łącznie pozbawiając życia kilkadziesiąt osób. Na wielkość strat powodziowych niebagatelny wpływ ma także koncentracja majątku w postaci zabudowy i infrastruktury w dolinach rzek, wzdłuż cieków. Podłoże np. zlewni Bystrzycy stanowią w dużej mierze gliny o niewielkiej miąższości (Stodolak i in. 2018), które cechują się średnią przepuszczalnością wody. W związku z czym przyczyniają się do zwiększenia odpływu powierzchniowego i szybszego formowania się wezbrań na ciekach.

Górna część zlewni Nysy Kłodzkiej zaliczana jest do tzw. kłodzkiego regionu klimatycznego sudeckiej dzielnicy klimatycznej (RZGW we Wrocławiu, 2013). Najniższe temperatury notowane są w Górach Bystrzyckich (średnia roczna $4,9^{\circ} \mathrm{C}$ ), najwyższe zaś na przedpolu Gór Opawskich (powyżej $8^{\circ} \mathrm{C}$ ) (RZGW we Wrocławiu, 2013). Roczne sumy opadów na analizowanym obszarze są zróżnicowane przestrzennie. Ogólnie wyższe wartości notuje się na terenach górskich, czyli na południu, zachodzie i wschodzie obszaru, szczególnie w zlewniach Bystrzycy Dusznickiej, Wilczki i górnej Białej Lądeckiej (ryc. 2). Wartości maleją natomiast w centralnej części oraz na północy obszaru, czyli w obrębie niżej położonej kotliny (ryc. 2). Spośród analizowanych posterunków opadowych najwyższe roczne sumy opadów notowane są w Zieleńcu $(1239 \mathrm{~mm})$, a najniższe w Kłodzku (585 mm). Opady w wieloleciu (ryc. 3), jak i w przebiegu miesięcznym (ryc. 4) są zróżnicowane.

\section{MATERIAŁY ŹRÓDŁOWE I METODY BADAŃ}

W pracy wykorzystano codzienne wartości przepływów z lat 1971-2015 dla ośmiu posterunków wodowskazowych, z czego trzy znajdują się na Nysie Kłodzkiej, a pozostałe na jej dopływach - Wilczce, Bystrzycy, Białej Lądeckiej i Bystrzycy Dusznickiej (ryc. 5). Wykorzystano także dane dotyczące opadów 


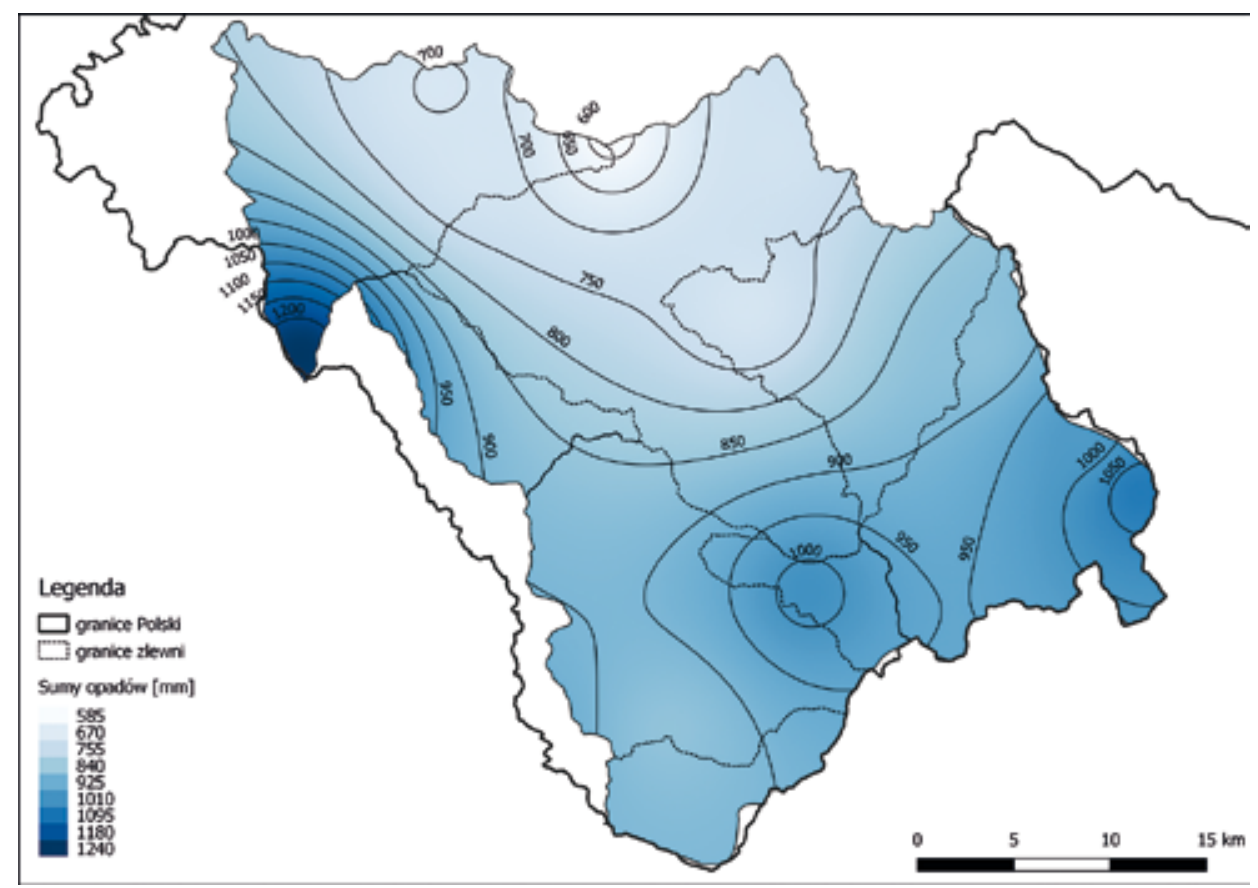

Ryc. 2. Średnie roczne opady dla analizowanych posterunków opadowych w latach 1971-2015

Fig. 2. Mean rainfall for analyzed precipitation gauges during 1971-2015

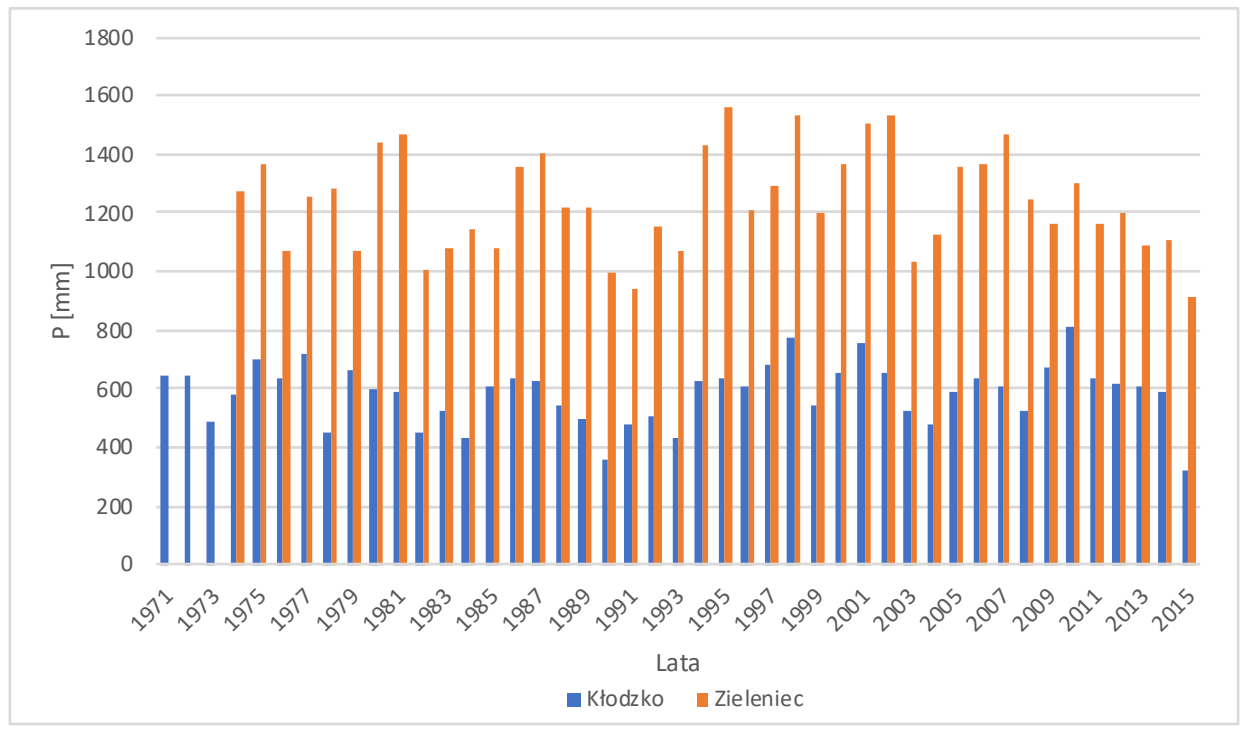

Ryc. 3. Wieloletnia zmienność rocznych opadów dla dwóch posterunków opadowych Fig. 3. Long-term variability of annual rainfall for two precipitation stations 


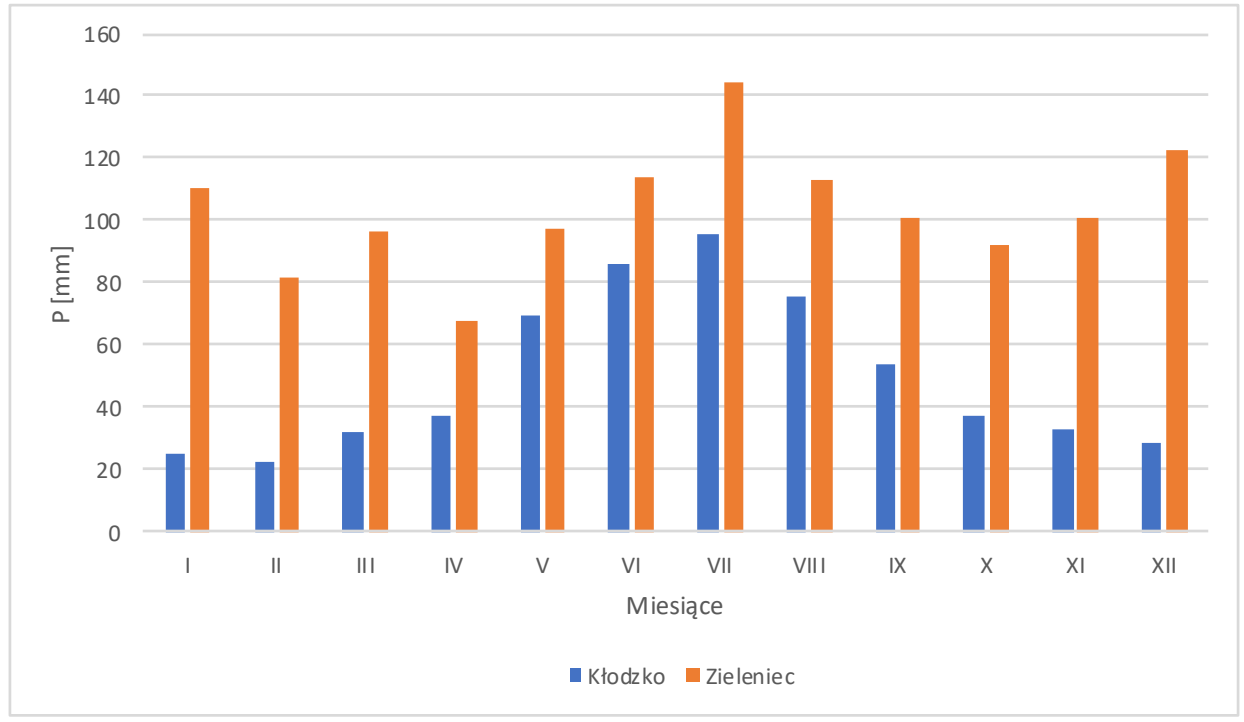

Ryc. 4. Rozkład opadów w przeciętnym cyklu rocznym dla stacji Kłodzko i Zieleniec

Fig. 4. The distribution of precipitation in the average annual cycle in Kłodzko and Zieleniec

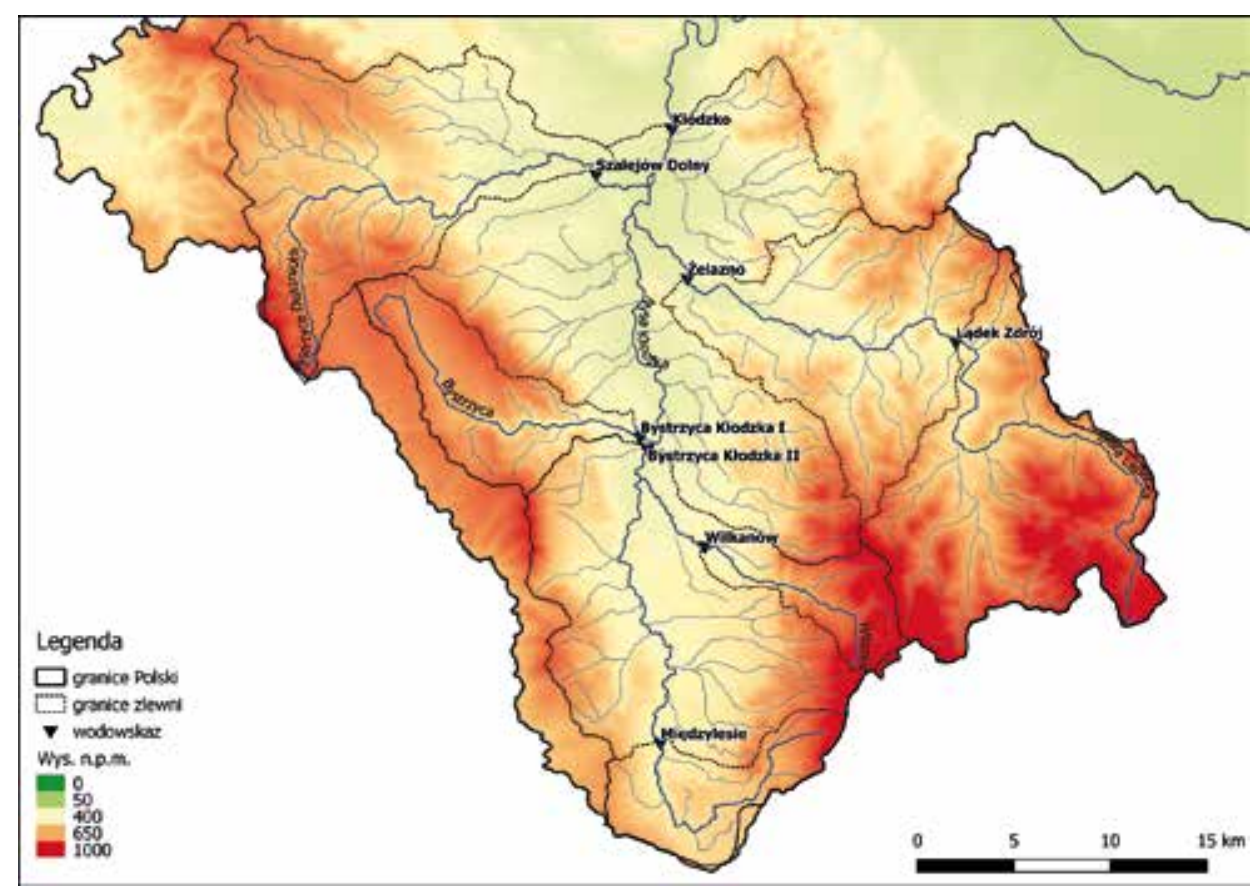

Ryc. 5. Rzeźba zlewni oraz lokalizacja rzek i posterunków wodowskazowych

Fig. 5. Landform of catchments and locations of rivers and gauge stations 
atmosferycznych dla 13 posterunków opadowych z lat 1971-2015. Pochodzą one z zasobów Instytutu Meteorologii i Gospodarki Wodnej - Państwowego Instytutu Badawczego.

W celu przeprowadzenia badania wykorzystano zarówno metody statystyczne do analizy danych hydrometrycznych, jak i graficzne do prezentacji wyników i ich przestrzennej interpretacji. Cechy reżimu odpływu ustalono przez wykorzystanie powszechnie stosowanych w hydrologii miar i wskaźników. Odpływ całkowity został scharakteryzowany przez wskaźnik odpływu $\mathrm{H}[\mathrm{mm}]$. Do ustalenia wielkości odpływu podziemnego wykorzystano przepływy charakterystyczne. Za przeciętną wielkość odpływu podziemnego uznano medianę ze zlinearyzowanych wartości minimów miesięcznych, uporządkowanych w rosnący szereg (Kille 1970). Kolejnym krokiem było obliczenie udziału odpływu podziemnego w odpływie całkowitym.

W pracy zmienność przepływów przedstawiono za pomocą współczynnika zmienności Cv [-]. Obliczono go dla przepływów dobowych oraz średnich, maksymalnych i minimalnych przepływów rocznych. Współczynnik ten jest stosunkiem odchylenia standardowego do średniej.

Analizę zróżnicowania typów reżimów poszczególnych zlewni cząstkowych oparto na kryteriach zaproponowanych przez Dynowską. Umożliwia to porównanie wyników z opracowaniami autorki - Atlasem Rzeczypospolitej Polskiej (1997), pracą Dynowskiej (1971) oraz pracą Dynowskiej i Pociask-Karteczki (1999). Mapę typów reżimów dla obszaru całego kraju przedstawił także Wrzesiński (2017b).

\section{STRUKTURA ODPŁYWU RZECZNEGO}

Odpływ całkowity w Kotlinie Kłodzkiej jest zróżnicowany (ryc. 6, tab. 2). Zlewnia Nysy Kłodzkiej po Kłodzko cechuje się odpływem w wysokości $375 \mathrm{~mm}$, większe wartości odpływu notowane są w jej zlewniach cząstkowych, zamkniętych wodowskazami w Międzylesiu (444 mm) i Bystrzycy Kłodzkiej II $(481 \mathrm{~mm})$. Największym odpływem całkowitym na badanym obszarze charakteryzuje się Wilczka po Wilkanów $(715 \mathrm{~mm})$, nieco mniejszym Biała Lądecka po Lądek Zdrój (649 mm). Z analizowanych dopływów Nysy Kłodzkiej najniższy odpływ ma Bystrzyca Dusznicka (388 mm). Wyraźnie wyższe odpływy notuje się we wschodniej części Kotliny, na prawych dopływach Nysy Kłodzkiej.

Średnie roczne odpływy jednostkowe (SSq) wahają się od 11,9 $\mathrm{dm}^{3} \cdot \mathrm{s}^{-1} \cdot \mathrm{km}^{-2}$ (Kłodzko) do $22,7 \mathrm{dm}^{3} \cdot \mathrm{s}^{-1} \cdot \mathrm{km}^{-2}$ (Wilkanów), średnie maksymalne roczne (SWq) od 108,2 $\mathrm{dm}^{3} \cdot \mathrm{s}^{-1} \cdot \mathrm{km}^{-2}$ (Bystrzyca Kłodzka I) do 201,9 $\mathrm{dm}^{3} \cdot \mathrm{s}^{-1} \cdot \mathrm{km}^{-2}$ (Bystrzyca Kłodzka II), a średnie minimalne roczne (SNq) od $2,5 \mathrm{dm}^{3} \cdot \mathrm{s}^{-1} \cdot \mathrm{km}^{-2}$ (Międzylesie, Bystrzyca Kłodzka II) do $6,5 \mathrm{dm}^{3} \cdot \mathrm{s}^{-1} \cdot \mathrm{km}^{-2}$ (Lądek Zdrój) (tab. 1). Przytoczone wartości wskazują na duże zróżnicowanie 


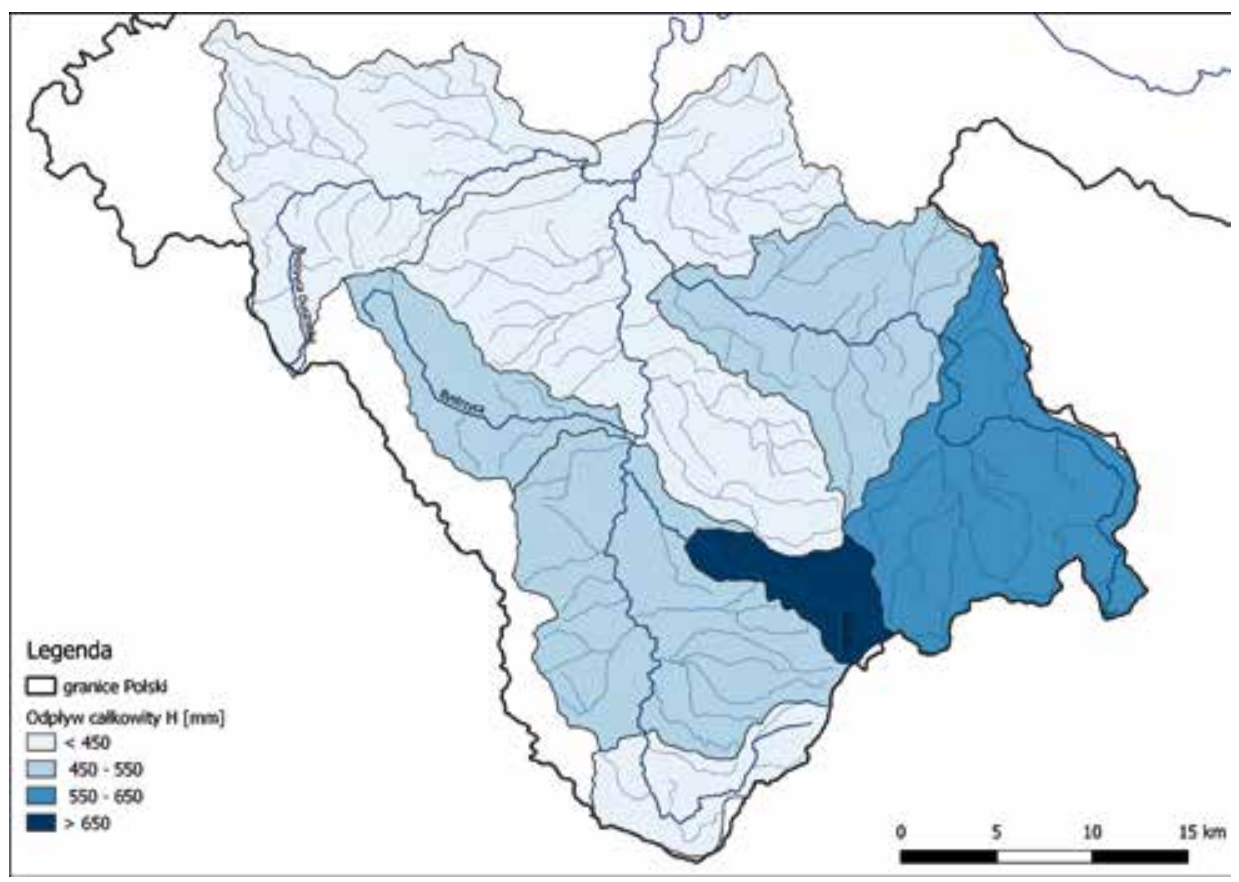

Ryc. 6. Przestrzenne zróżnicowanie wskaźnika odpływu

Fig. 6. Spatial differentiation of the runoff indicator

warunków wodnych w analizowanych zlewniach. Przykładowo Wilczka charakteryzuje się bardzo niskim średnim przepływem, co jednak przekłada się na najwyższy odpływ jednostkowy na badanym obszarze w związku z małą powierzchnią zlewni. Ekstrema absolutne $z$ wielolecia (WWQ oraz NNQ) wskazują na bardzo duże zróżnicowanie wielkości przepływów. Stosunek największego odnotowanego przepływu do najniższego waha się od $107 \mathrm{dm}^{3} \cdot \mathrm{s}^{-1} \cdot \mathrm{km}^{-2}$ do $2473 \mathrm{dm}^{3} \cdot \mathrm{s}^{-1} \cdot \mathrm{km}^{-2}$ (tab. 1). Rekordzistami w nieregularności przepływów są Biała Lądecka (Żelazno) oraz Nysa Kłodzka (Bystrzyca Kłodzka II), natomiast najbardziej regularnymi przepływami w skali wielolecia charakteryzuje się Bystrzyca.

Nieco inaczej kształtuje się rozkład przestrzenny odpływu podziemnego (ryc. 7). Większość zlewni charakteryzuje się odpływem podziemnym między $150 \mathrm{~mm}$ a $250 \mathrm{~mm}$, odpływ podziemny z całego analizowanego obszaru to $166 \mathrm{~mm}$ (tab. 2). Najniższe wartości notowane są w zlewni Nysy Kłodzkiej po profil Bystrzyca Kłodzka II. Jest to jedyna zlewnia, w której odpływ podziemny kształtuje się na poziomie poniżej $150 \mathrm{~mm}$. Najwyższe wartości, podobnie jak w przypadku odpływu całkowitego, cechują zlewnię Wilczki (368 mm). Drugą co do wielkości wartością odpływu podziemnego jest zlewnia Białej Lądeckiej po Lądek Zdrój. 


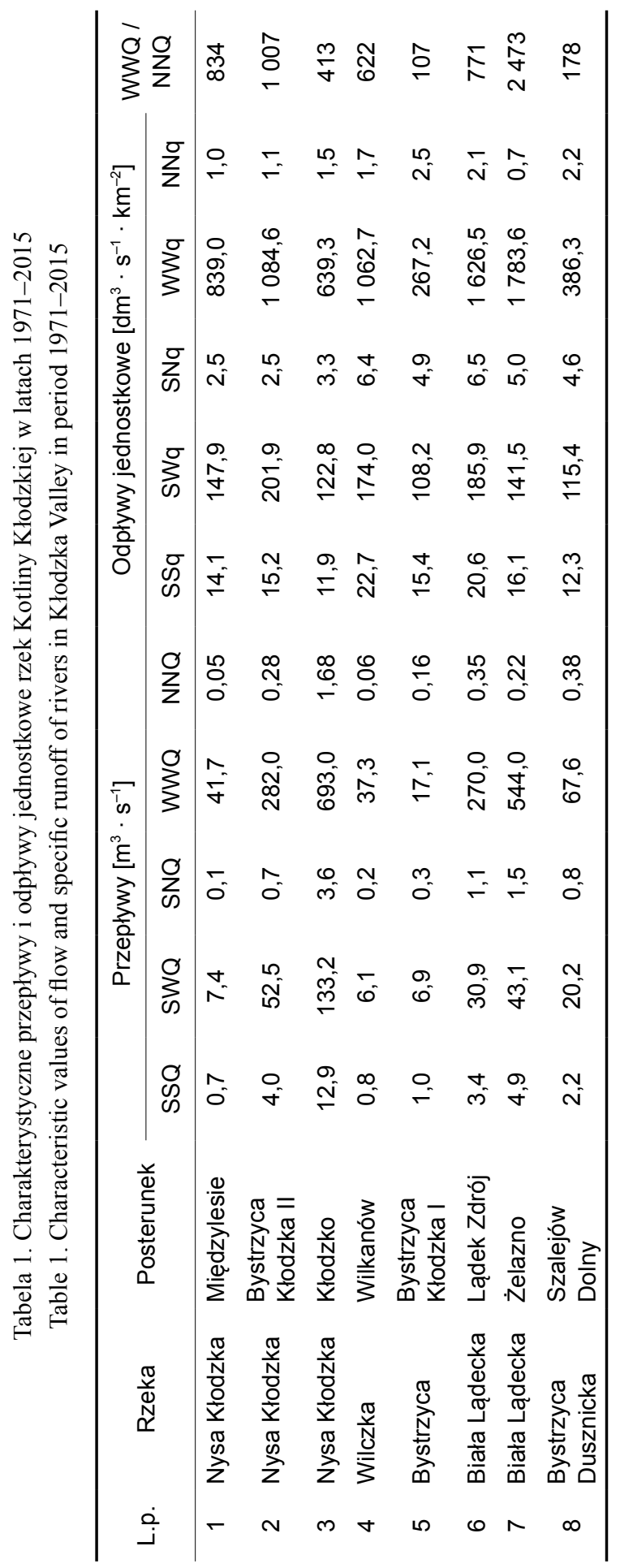




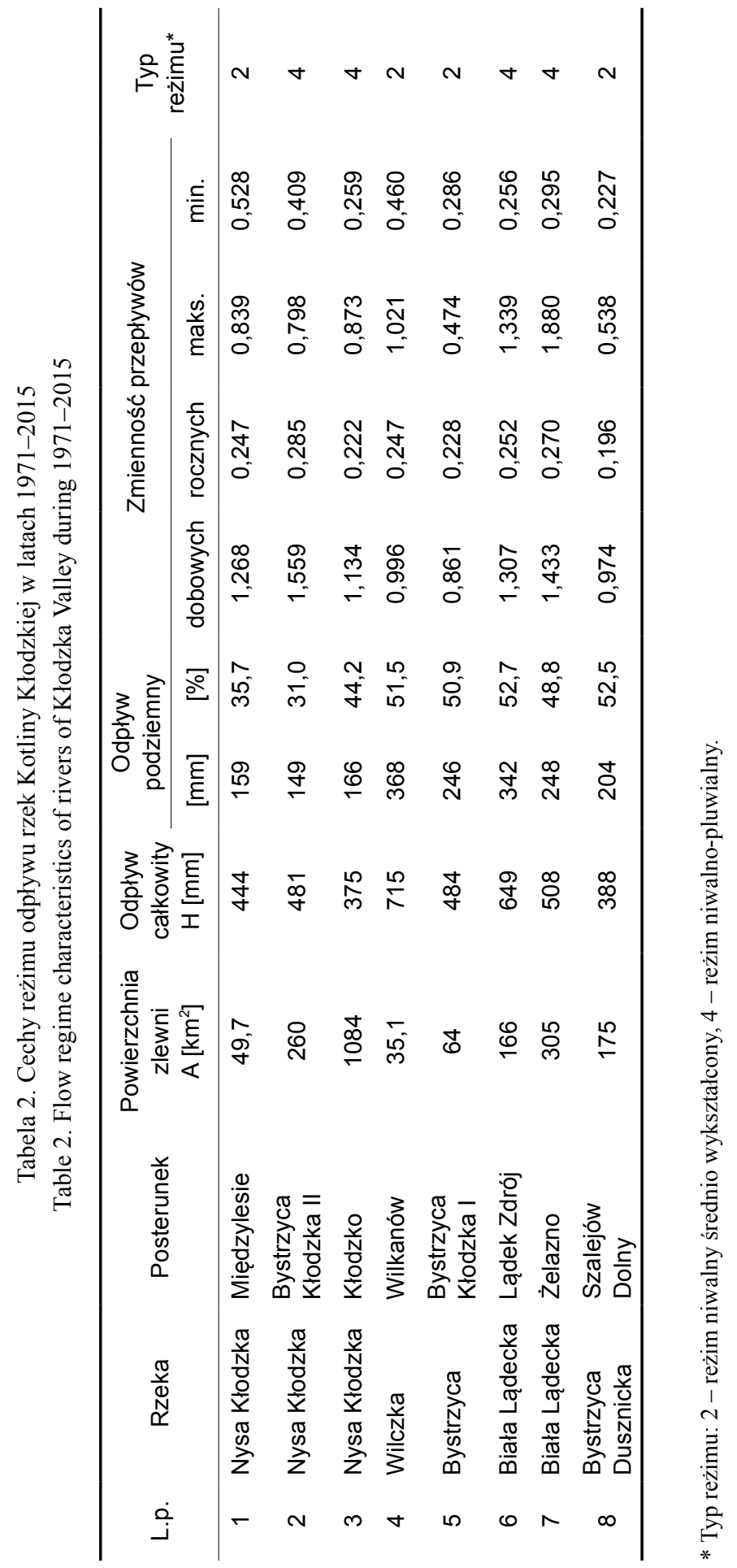




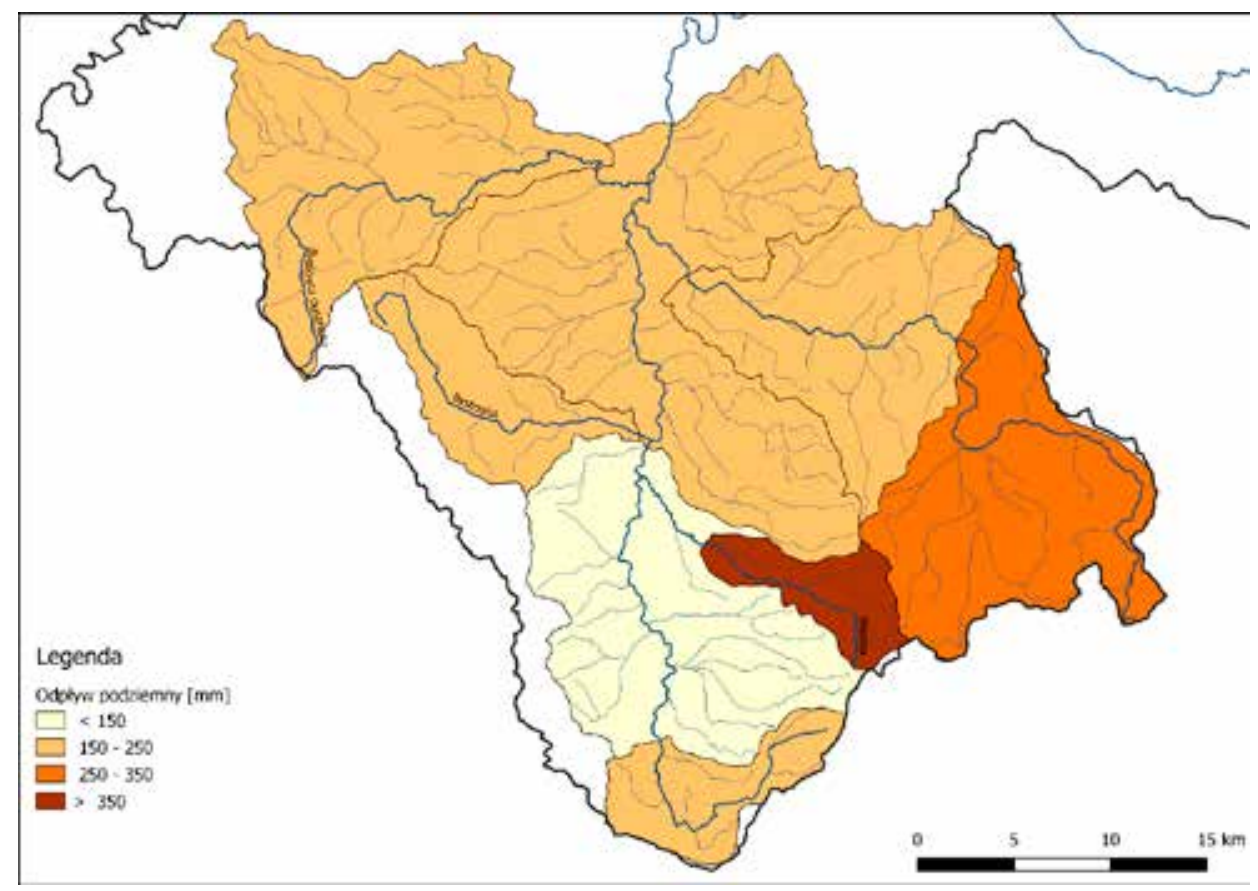

Ryc. 7. Rozkład przestrzenny wskaźnika odpływu podziemnego

Fig. 7. Spatial differentiation of the underground outflow indicator

Bardziej szczegółowy obraz zróżnicowania warunków odpływu Kotliny Kłodzkiej wynika $\mathrm{z}$ analizy udziału odpływu podziemnego w odpływie całkowitym. Na podstawie stosunku tych wartości można wnioskować o różnicach w zasobności wodnej poszczególnych zlewni, informuje on o zdolności retencyjnej obszaru. Na terenie Kotliny Kłodzkiej szczególnie niskim udziałem odpływu podziemnego w odpływie całkowitym wyróżniają się dwie zlewnie górnej Nysy Kłodzkiej, zamknięte profilami wodowskazowymi Międzylesie i Bystrzyca Kłodzka II (ryc. 8). Analizowana zmienna przyjmuje w tych zlewniach odpowiednio: 35,7\% i 31,0\% (tab. 2). Całość badanego obszaru cechuje się udziałem zasilania podziemnego na poziomie $44,2 \%$. Połowa analizowanych zlewni odznacza się udziałem odpływu podziemnego większym niż udział odpływu powierzchniowego, czyli przekraczającym 50\%. Najwyższą wartość odnotowano w zlewni Białej Lądeckiej po Lądek Zdrój (52,7\%). Należy zauważyć, że wszystkie zlewnie charakteryzują się mniejszą zdolnością retencyjną niż wynosi średnia krajowa (ok. 55\%) (Jokiel 1994). Często większość wód opadowych i roztopowych odpływa więc w postaci spływu powierzchniowego, co z jednej strony przyczynia się do szybkiego powstawania wezbrań na rzekach (charakterystycznych dla zlewni górskich), a z drugiej strony zagrożenia występowaniem suszy hydrogeologicznej i hydrologicznej. 


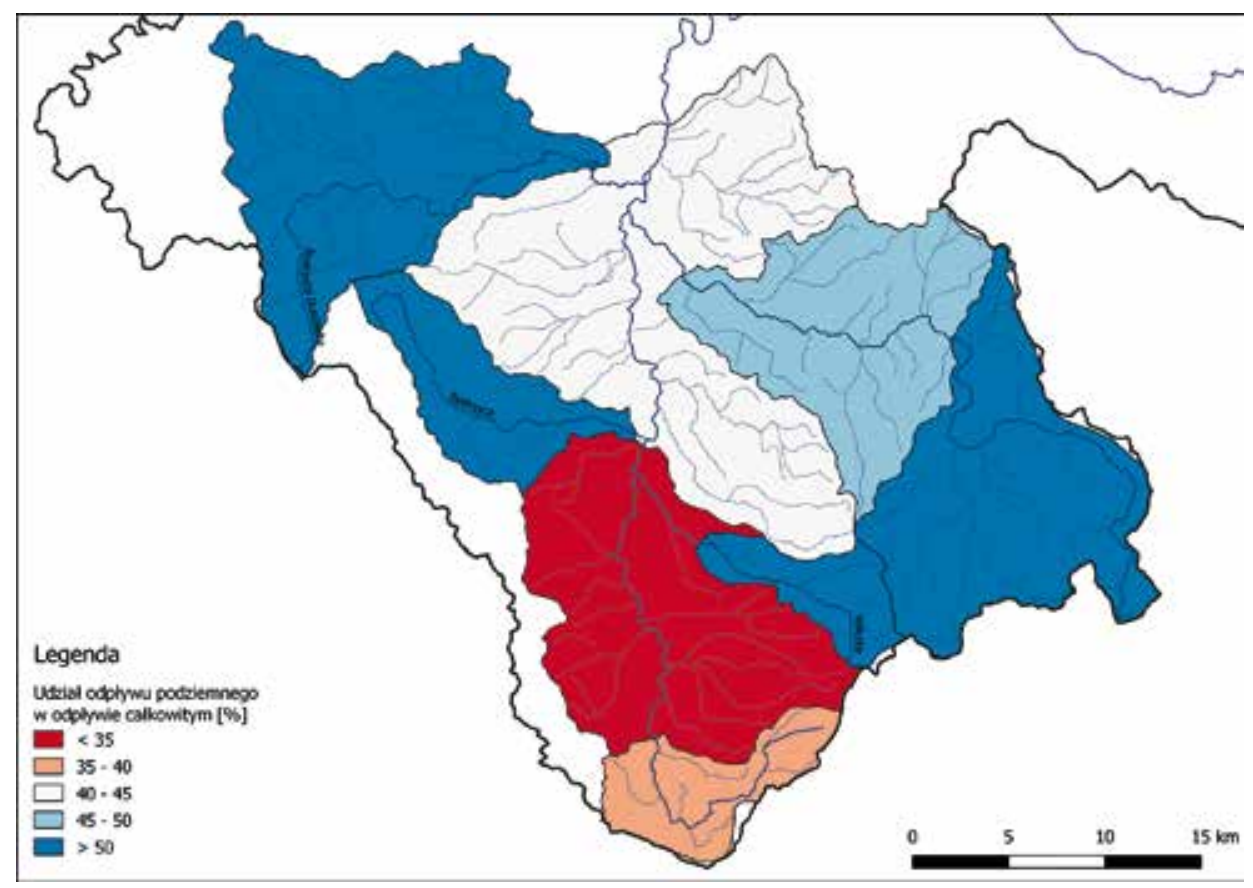

Ryc. 8. Udział odpływu podziemnego w odpływie całkowitym

Fig. 8. Ratio of underground flow volume in the total flow

\section{ZMIENNOŚĆ PRZEPŁYWÓW}

Zmienność przepływów jest istotną miarą pozwalającą na dalszą charakterystykę reżimu odpływu. W niniejszej pracy obliczono i przeanalizowano cztery miary zmienności przepływów - dobowych, średnich rocznych, a także maksymalnych i minimalnych rocznych.

Krótkookresowe zmiany wielkości odpływu mają charakter przede wszystkim sezonowy, będący konsekwencją cyklu zmian wielkości i form zasilania w ciągu roku hydrologicznego. Oprócz tego zmienność odpływu determinują cechy środowiska przyrodniczego, decydujące o zdolności retencyjnej zlewni.

\section{Przepływy dobowe}

Najwyższą zmiennością przepływów dobowych cechują się odcinki Nysy Kłodzkiej i Białej Lądeckiej (ryc. 9A) - Cv dla zlewni Nysy Kłodzkiej zamkniętej profilem Bystrzyca Kłodzka II wynosi 1,559, a dla zlewni Białej Lądeckiej po Żelazno 1,433. Zlewnie te odznaczają się stosunkowo niskim udziałem odpływu podziemnego w odpływie całkowitym. 
Najbardziej stabilne (czyli o najmniejszej zmienności przepływów) są przepływy Wilczki, Bystrzycy oraz Bystrzycy Dusznickiej $(\mathrm{Cv}<1,00)$. Należy zauważyć, że zlewnie tych rzek cechuje wyższy niż pozostałych zlewni udział odpływu podziemnego w odpływie całkowitym (ryc. 8), co bezpośrednio przekłada się na mniejszą zmienność przepływów dobowych. Warto jednak zwrócić uwagę na fakt, że stosunek największej obliczonej zmienności do najniższej na badanym obszarze wynosi około 1,8, a np. w zlewni Warty aż około 5,2 (Wrzesiński, Perz 2016). Świadczy to o stosunkowo niewielkich różnicach między zmiennością przepływów dobowych analizowanych rzek w porównaniu z innymi obszarami w Polsce. W profilu Kłodzko, zamykającym analizowany obszar, zmienność przepływów dobowych wynosi 1,134.

\section{Średnie przepływy roczne}

Rozkład przestrzenny zmienności średnich przepływów rocznych (ryc. 9B) nieco odbiega od zaobserwowanego dla przepływów dobowych (ryc. 9A), jednak także wyróżniają się odcinki Nysy Kłodzkiej oraz Białej Lądeckiej, gdzie odnotowano najwyższe wartości zmienności - odpowiednio: 0,285 i 0,270. Najmniejszą zmiennością przepływów rocznych cechuje się Bystrzyca Dusznicka $(0,196)$. Nysa Kłodzka w Kłodzku charakteryzuje się zmiennością równą 0,222. W tym przypadku także należy podkreślić, że zdiagnozowane różnice zmienności średnich przepływów rocznych w zlewniach Kotliny Kłodzkiej są stosunkowo niewielkie.

\section{Przepływy maksymalne roczne}

Zmienność przepływów maksymalnych rocznych jest zdecydowanie większa niż średnich przepływów rocznych. W analizie przestrzennej wyróżnia się Biała Lądecka (ryc. 9C), gdzie w profilu Żelazno zmienność wynosi 1,880, najniższa wartość $(0,474)$ została obliczona dla Bystrzycy. Świadczy to o możliwości występowania na Białej Lądeckiej wezbrań o skrajnie różnej wielkości w poszczególnych latach. Zmienność przepływów Białej Lądeckiej wpływa na zmienność przepływów Nysy Kłodzkiej - w jej górnym odcinku zmienność delikatnie spada wraz z biegiem rzeki (Międzylesie - 0,839, Bystrzyca Kłodzka II $-0,798$ ), natomiast w profilu Kłodzko jest znowu wyższa i wynosi 0,873. Zatem zarówno w przypadku Nysy Kłodzkiej, jak i Białej Lądeckiej mamy do czynienia z dość szczególną sytuacją, w której zmienność przepływów maksymalnych rocznych rośnie wraz z biegiem rzeki (ryc. 9C). 


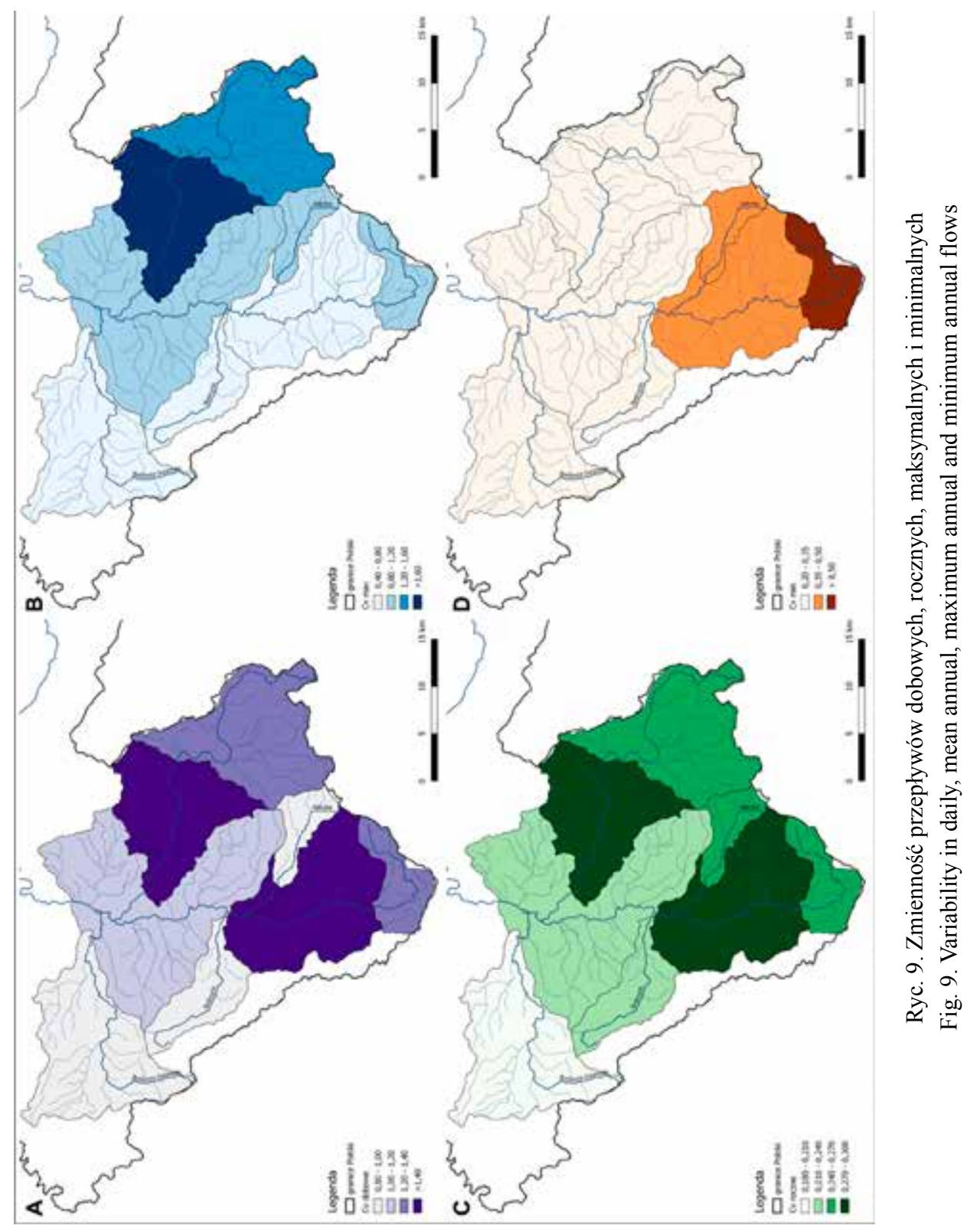




\section{Przepływy minimalne roczne}

W przypadku przepływów minimalnych rocznych sytuacja jest odmienna (ryc. 9D). Zmienność jest tu niska i waha się od 0,227 do 0,528, przy czym na większości posterunków wodowskazowych kształtuje się na poziomie poniżej 0,350. Najwyższą zmiennością cechuje się górny odcinek Nysy Kłodzkiej (posterunki Międzylesie i Bystrzyca Kłodzka II). Jest to obszar o bardzo niskim udziale odpływu podziemnego w odpływie całkowitym (poniżej 40\%), a z tym wiąże się niska zdolność retencyjna. Taka sytuacja może powodować występowanie głębokich niżówek i silnej zależności wielkości przepływów minimalnych rocznych od zasilania deszczowego lub śnieżnego.

\section{TYPY REŻIMU}

Ostatnim etapem pracy było ustalenie typów reżimów. W tym celu posłużono się klasyfikacją Dynowskiej (1999). Dynowska (1971) zakwalifikowała rzeki regionu Kotliny Kłodzkiej wraz z otaczającymi ją górami do reżimu umiarkowanego $\mathrm{z}$ wezbraniem wiosennym, letnim i zimowym oraz gruntowo-deszczowo-śnieżnym zasilaniem. Wrzesiński $(2013,2017 b)$ na mapie reżimu odpływu rzek w Polsce obszar Kotliny Kłodzkiej zakwalifikował do reżimów niwalno-pluwialnego oraz pluwialno-niwalnego, opierał się jednak na danych z innego wielolecia niż autor niniejszej pracy. Na podstawie danych z lat 1971-2015, z uwagi na rozkład odpływu w roku hydrologicznym, wyrażony przebiegiem i wysokością miesięcznych współczynników przepływu, badane cieki zaliczono do dwóch spośród pięciu typów reżimów:

Typ 2 - reżim niwalny średnio wykształcony. Średni przepływ miesiąca wiosennego (marzec-kwiecień) stanowi 130-180\% średniego przepływu rocznego. Ten typ reżimu jest charakterystyczny dla górnego odcinka Nysy Kłodzkiej (po Międzylesie) oraz jej lewobrzeżnych dopływów - Bystrzycy i Bystrzycy Dusznickiej (ryc. 10 i ryc. 11).

Typ 4 - reżim niwalno-pluwialny. Średni przepływ miesiąca wiosennego (marzec-kwiecień), podobnie jak w typie 2, wynosi 130-180\% średniego przepływu rocznego. Wyraźnie zaznacza się wzrost średniego przepływu w miesiącach letnich, który wynosi co najmniej $100 \%$ średniego przepływu rocznego. Tym typem reżimu charakteryzuje się Nysa Kłodzka poniżej Międzylesia, a także Biała Lądecka oraz Wilczka (ryc. 10 i ryc. 12).

Różnice między dwoma zidentyfikowanymi reżimami bardzo dobrze widać na wykresach (ryc. 11 i ryc. 12). Najwyższe współczynniki przepływu w przypadku reżimu niwalnego średnio wykształconego notowane są w marcu i kwietniu. W porównaniu z reżimem niwalno-pluwialnego nie uwidacznia się tak wyraźnie drugi okres zwiększonych przepływów w lipcu. 


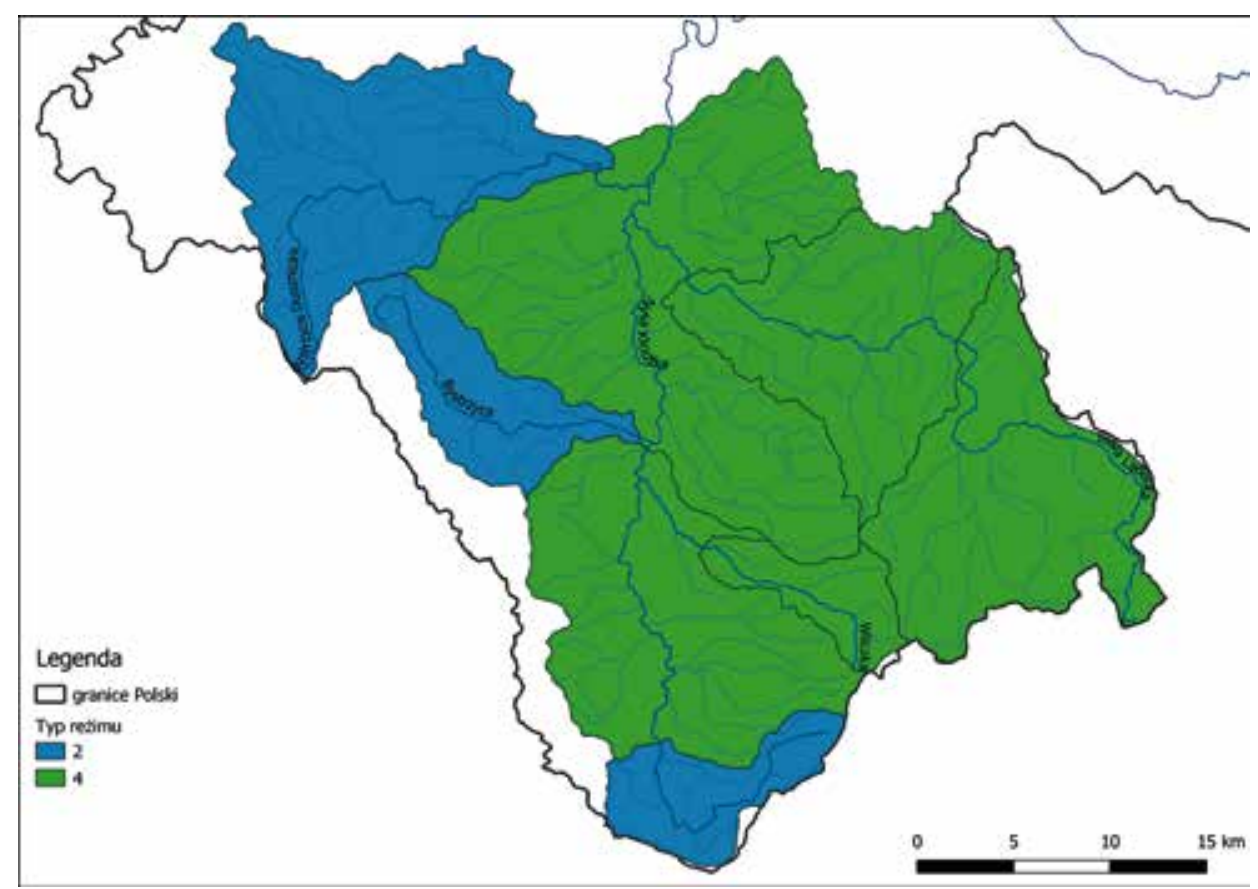

Ryc. 10. Typy reżimu odpływu rzek

Fig. 10. Runoff regime types

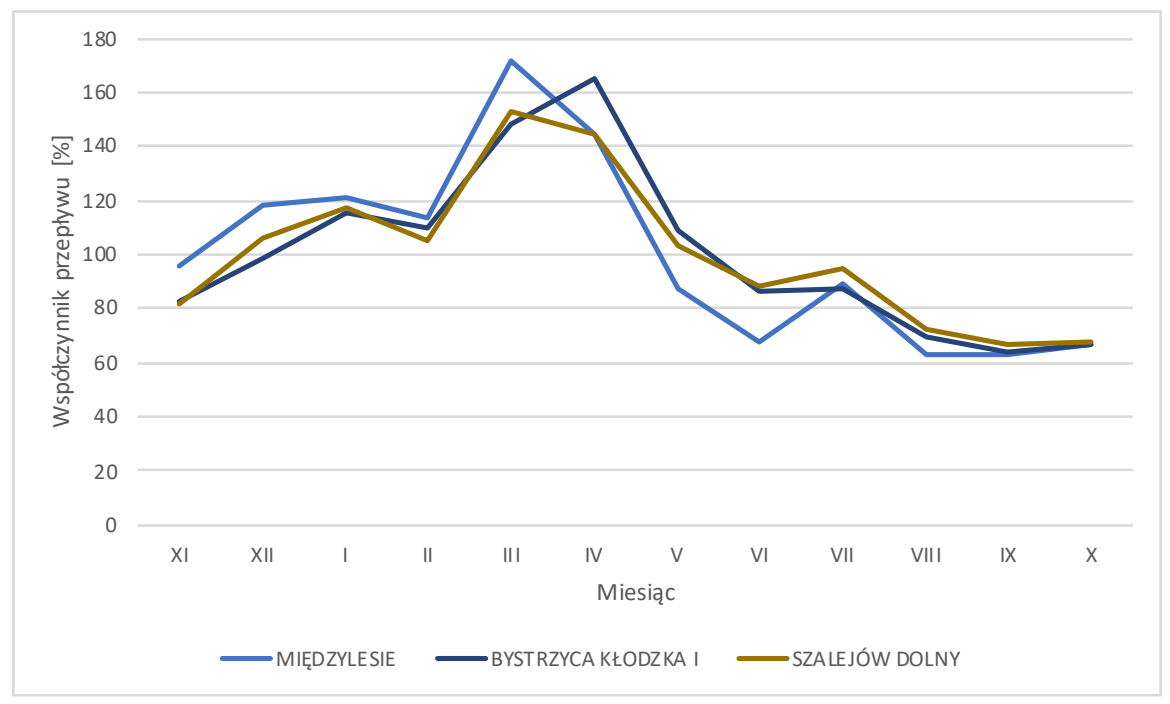

Ryc. 11. Przebieg miesięcznych współczynników przepływu w posterunkach charakteryzujących się drugim typem reżimu według Dynowskiej (1999) (niwalny średnio wykształcony)

Fig. 11. The course of the coefficients of flow of gauge stations with $2^{\text {nd }}$ hydrological regime type by Dynowska (1999) (nival, moderately developed) 


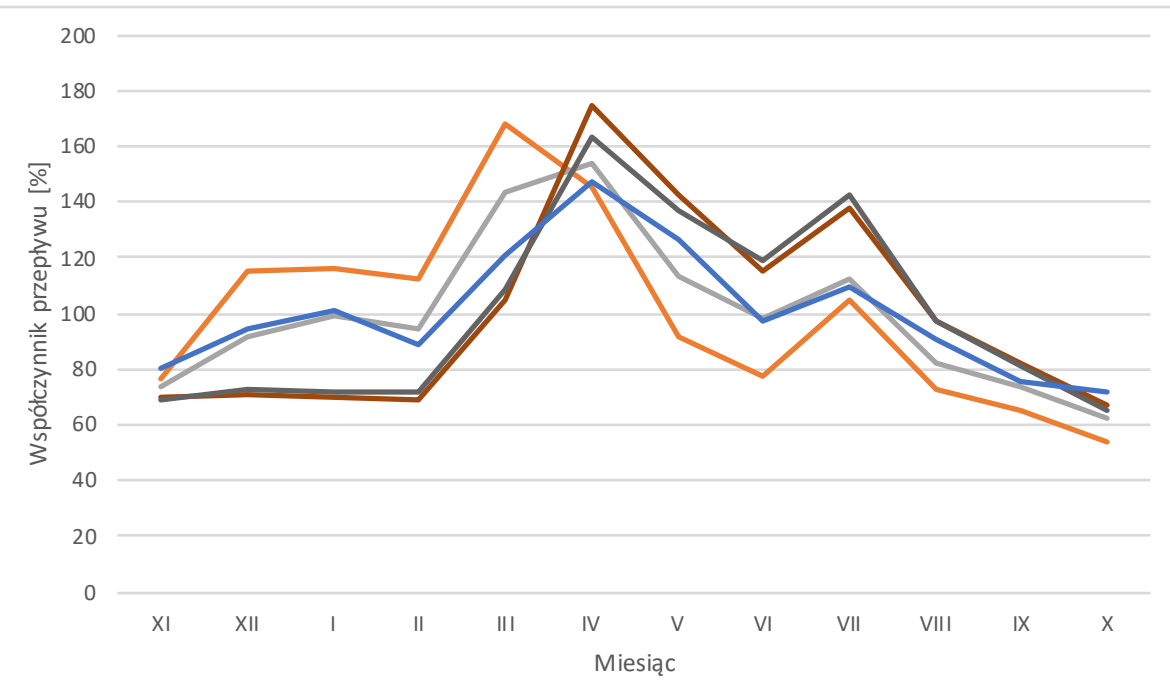

Ryc. 12. Przebieg miesięcznych współczynników przepływu w posterunkach charakteryzujących się czwartym typem reżimu według Dynowskiej (1999) (niwalno-pluwialny)

Fig. 12. The course of the coefficients of flow of gauge stations with $4^{\text {th }}$ hydrological regime type by Dynowska (1999) (nivo-pluvial)

Porównując przedstawiony rozkład reżimów (ryc. 10) z rozkładem miesięcznym sum opadów (ryc. 4), można zauważyć, że na stacji Zieleniec (okolice zlewni Bystrzycy Dusznickiej i Bystrzycy) notowane są wysokie opady nie tylko w lipcu, ale także w miesiącach zimowych. Może to przekładać się na inną kwalifikację reżimu tych rzek (reżim niwalny średnio wykształcony).

\section{WNIOSKI I PODSUMOWANIE}

Mimo stosunkowo niewielkich rozmiarów badany obszar charakteryzuje się różnymi warunkami odpływu w poszczególnych zlewniach. Należy podkreślić, że w przypadku niektórych wskaźników różnice są zauważalne, jednakże w porównaniu z innymi obszarami kraju stosunkowo małe (por. Wrzesiński, Perz 2016). Jednak nawet te stosunkowo niewielkie zróżnicowanie ostatecznie wpływa na różną kwalifikację poszczególnych zlewni pod względem typu reżimu (ryc. 10).

Wschodnia część obszaru (Wilczka i Biała Lądecka) pod względem wielu parametrów odstaje od pozostałych analizowanych zlewni. Cechują się one wyraźnie wyższym odpływem całkowitym i podziemnym, Biała Lądecka odznacza się także wysoką zmiennością przepływów dobowych, średnich i maksymalnych rocznych. Ciekawie przedstawia się również podział obszaru na dwa typy 
reżimu, co świadczy o zróżnicowanych źródłach zasilania rzek oraz o różnej dynamice przepływów w ciągu roku. Potwierdza to różny rozkład opadów w ciągu roku w poszczególnych częściach analizowanego obszaru.

Badany obszar znany jest z często występujących powodzi i gwałtownych wezbrań. Częściowo mogą być za to odpowiedzialne zmiany zagospodarowania terenu, zarówno antropogeniczne (znaczne wylesienie, uszczelnianie powierzchni, rosnąca presja turystyczna, budowa wałów transferujących fale wezbraniowe w niższe partie zlewni), jak i naturalne (np. wiatrołomy, układ hydrograficzny). Nysa Kłodzka w naturalny sposób kumuluje wody spływające $\mathrm{z}$ otaczających ją górskich terenów, wzdłuż jej biegu występuje kilka istotnych węzłów hydrograficznych powodujących w warunkach wysokich opadów lub gwałtownych odwilży bardzo szybkie formowanie się fal powodziowych. Bednorz $i$ in. (2019) wskazali na istotną rolę warunków synoptycznych na występowanie powodzi oraz na niemal natychmiastową reakcję w postaci ekstremalnych odpływów rzek. Autorzy przyczyn takiego stanu upatrują w niskiej zdolności retencyjnej związanej z pochyłością terenu oraz niską przepuszczalnością podłoża, co potwierdza m.in. niski udział odpływu podziemnego w odpływie całkowitym (ryc. 8).

W przeszłości, jak i obecnie, jako odpowiedź na istniejące zagrożenie powodziowe oraz historycznie występujące tutaj wielkie powodzie, na rzekach Kotliny Kłodzkiej realizowane są inwestycje przeciwpowodziowe, $\mathrm{w}$ tym budowa suchych zbiorników przeciwpowodziowych, np. w ramach projektu „Ochrona przeciwpowodziowa w dorzeczu Odry i Wisły", finansowanego ze środków Międzynarodowego Banku Odbudowy i Rozwoju (Bank Światowy) oraz Banku Rozwoju Rady Europy, jak również przy wsparciu środków z Funduszu Spójności UE oraz budżetu państwa.

\section{LITERATURA}

Bednorz E., Wrzesiński D., Tomczyk A.M., Jasik D., 2019: Classification of Synoptic Conditions of Summer Floods in Polish Sudeten Mountains. Water, 11, 1450.

Dubicki A., Słota H., Zieliński J., 1999: Dorzecze Odry: Monografia powodzi lipiec 1997. IMGW, Warszawa.

Dynowska I., 1971: Typy reżimów rzecznych w Polsce. Zesz. Nauk. UJ, Pr. Geogr., 28.

Dynowska I., Pociask-Karteczka J., 1999: Obieg wody, [w:] L. Starkel (red.), Geografia Polski. Środowisko przyrodnicze. Wyd. Nauk. PWN, Warszawa, 343-373.

Jeziorska J., Niedzielski T., 2018: Applicability of TOPMODEL in the mountainous catchments in the upper Nysa Kłodzka river basin (SW Poland). Act. Geoph., 66, 2, 203-222.

Jokiel P., 1994: Zasoby, odnawialność, i odplyw wód podziemnych strefy aktywnej wymiany w Polsce. Act. Geograph. Lodz., 66-67.

Kille K., 1970: Das Verfahren MoMNQ, ein Beitrag zur Berechnung der mittleren langjährigen Grundwasserneubildung mit Hilfr der monatlichen Niedrigwasserabflüsse. Z. Deutch., Geol. Ges., Sonderh., Hydrogeol., Hydrogeochem., Hannover.

Kondracki J., 2013: Geografia regionalna Polski. Wyd. Nauk. PWN, Warszawa. 
Łach J., 2009: Historia wezbrań powodziowych na Ziemi Kłodzkiej i ich wpływ na kierunek przekształceń den dolinnych Nysy Kłodzkiej i Białej Ladeckiej. Nauka Przyroda Technologie, t. 3,3 .

Łach J., 2012: Rola gwałtownych ulew i powodzi w modelowaniu rzeźby Kotliny Kłodzkiej oraz zachodnich pasm górskich Sudetów Wschodnich. Inst. Geogr. i Rozw. Reg. UWr, Wrocław.

Morawska-Horawska M., 1971: Meteorologiczne przyczyny powodzi w Polsce poludniowej w lipcu 1970 roku. Przegl. Geofiz., 4, 299-315.

Niedzielski T., Miziński B., 2017: Real-time hydrograph modelling in the upper Nysa Kłodzka river basin (SW Poland): a two-model hydrologic ensemble prediction approach. Stochastic Environmental Res. and Risk Assessment, 31, 6, 1555-1576.

Rutkowska A., Willems P., Niedzielski T., 2017: Relation between design floods based on daily maxima and daily means: use of the Peak Over Threshold approach in the Upper Nysa Kłodzka Basin (SW Poland). Geomatics, Natural Hazards and Risk, 8, 2, 585-606.

RZGW we Wrocławiu, 2013: Opracowanie charakterystyki zlewni bilansowej rzeki Nysy Kłodzkiej.

Solon J., Borzyszkowski J., Bidłasik M., Richling A., Badora K., Balon J., et al. podać wszystkich autorów 2018: Physico-geographical mesoregions of Poland: verification and adjustment of boundaries on the basis of contemporary spatial data. Geogr. Pol., 91(2), 143-170.

Staff M. (red.), 1993: Stownik geografii turystycznej Sudetów. T. 15: Kotlina Kłodzka i Rów Górnej Nysy. I-BiS, Wrocław, 315-318.Stodolak R., Baran J., Knap E., 2018: Wpływ przyjętych rozkładów czasowych zmienności deszczu na wyniki modelowania opad-odplyw. Inż. Ekol., 19(6), 87-93.

Szalińska W., Otop I., Tokarczyk T., 2014: Precipitation extremes Turing flooding in the Odra River Basin in May-June 2010. Meteor. Hydr. Water Manag. Res. Oper. Appl., 2, 13-20.

Szalińska W., Tokarczyk T., Jełowicki J., Chorążyczewski A., Michalski A., Tiukało A., Ostojski M., 2014: Środowisko obliczeniowe operacyjnego modelu typu opad-odptyw. Monogr. Kom. Gosp. Wodnej PAN, z. 20.

Świątek M., 2013: Advection of air masses responsible for extreme rainfall totals in Poland, as exemplified bycatastrophic floods in Racibórz (July 1997) and Dobczyce (May 2010). Act. Agrophys., 20, 481-494.

Tokarczyk T., Olearczyk D., 2011: Hydrografia Ziemi Kłodzkiej. Starostwo Powiatowe w Kłodz$\mathrm{ku}$.

Wrona B., 2008: Meteorologiczne i morfologiczne uwarunkowania ekstremalnych opadów atmosferycznych $w$ dorzeczu górnej i środkowej Odry. Mat. Bad., Ser.: Meteor., 41, IMGW, Warszawa.

Wrzesiński D., 2013: Entropia odpływu rzek w Polsce. Bogucki Wyd. Nauk., Poznań.

Wrzesiński D., 2017a: Typologia reżimu odpływu rzek w Polsce w podejściu nadzorowanym i nienadzorowanym. Bad. Fizjograf., R. 8, Ser. A - Geogra. Fiz. (A68), PTPN, Poznań, 253-264.

Wrzesiński D., 2017b: Reżimy rzek Polski, [w:] P. Jokiel, W. Marszelewski, J. Pociask-Karteczka (red.), Hydrologia Polski. Wyd. Nauk. PWN, Warszawa, 215-221.

Wrzesiński D., Perz A., 2016: Cechy reżimu odpływu rzek w zlewni Warty. Bad. Fizjograf., R. 7, Ser. A - Geogr. Fiz. (A67), PTPN, Poznań, 289-304. 